\title{
Application of microextraction by packed sorbent to isolation of psychotropic drugs from human serum
}

\author{
Renata Wietecha-Posłuszny • Aneta Garbacik • \\ Michał Woźniakiewicz • Agnieszka Moos • \\ Marcin Wieczorek • Pawel Kościelniak
}

Received: 15 July 2011 /Revised: 14 September 2011 / Accepted: 23 September 2011 /Published online: 16 October 2011

(C) The Author(s) 2011. This article is published with open access at Springerlink.com

\begin{abstract}
A method of microextraction by packed sorbent (MEPS) followed by liquid chromatography with diode array detection has been developed and optimized for the extraction of six tricyclic antidepressants (amitriptyline, nortriptyline, imipramine, desipramine, doxepin, nordoxepin) from human serum. The optimal parameters of MEPS extraction (type of sorbent, volume of sample, composition, and volume of washing and elution solutions) for these drugs in spiked samples were defined. The developed MEPS procedure was validated and then successfully applied to the analysis of serum reference material. The limit of detection $(0.02-0.05 \mu \mathrm{g} / \mathrm{mL})$, intraday $(2.7-8.8 \%)$ and interday (4.4-11.6\%) precision (RSD), and the accuracy of the assay (94.5-108.8\%) at three concentration levels - $0.2,0.5$, and $0.8 \mu \mathrm{g} / \mathrm{mL}$ - were estimated. The accuracy of the method was evaluated by the analysis of certified reference material. Moreover, the validated procedure was compared with the solid-phase extraction technique. Finally, microextraction by packed sorbent was assessed as a suitable tool in forensic and clinical methods for serum sample preparations.
\end{abstract}

Published in the special issue Analytical and Bioanalytical Science in Poland with guest editor Marek Biziuk.

R. Wietecha-Posłuszny $(\bowtie) \cdot$ A. Garbacik $\cdot$ M. Woźniakiewicz •

A. Moos $\cdot$ M. Wieczorek $\cdot$ P. Kościelniak

Laboratory for Forensic Chemistry, Department of Analytical

Chemistry, Jagiellonian University,

3 Ingardena St.,

30-060 Kraków, Poland

e-mail: wietecha@chemia.uj.edu.pl

P. Kościelniak

Institute of Forensic Research,

9 Westerplatte St.,

31-033 Kraków, Poland
Keywords Tricyclic antidepressant drugs · Microextraction by packed sorbent . Solid-phase extraction .

High-performance liquid chromatography .

Human serum samples

$\begin{array}{ll}\text { Abbreviations } & \\ \text { Ami } & \text { Amitriptyline } \\ \text { BIN } & \text { Barrel insert and needle assembly } \\ \text { Clo } & \text { Clomipramine } \\ \text { Des } & \text { Desipramine } \\ \text { Dox } & \text { Doxepin } \\ \text { GC-MS } & \text { Gas chromatography with mass } \\ & \text { spectrometry detection } \\ \text { HPLC-DAD } & \text { High-performance liquid chromatography } \\ & \text { with diode array detection } \\ \text { Imi } & \text { Imipramine } \\ \text { IS } & \text { Internal standard } \\ \text { LC-UV } & \text { Liquid chromatography with } \\ & \text { ultraviolet detection } \\ \text { LLE } & \text { Liquid-liquid extraction } \\ \text { LOD } & \text { Limit of detection } \\ \text { LOQ } & \text { Limit of quantification } \\ \text { LPME } & \text { Liquid-liquid microextraction } \\ \text { MeOH } & \text { Methanol } \\ \text { MEPS } & \text { Microextraction by packed sorbent } \\ \text { Nord } & \text { Nordoxepin } \\ \text { Nort } & \text { Nortriptyline } \\ \text { SCX } & \text { Cation exchange sorbent } \\ \text { SPE } & \text { Solid-phase extraction } \\ \text { SPME } & \text { Solid-phase microextraction } \\ \text { SSRIs } & \text { Selective serotonin reuptake inhibitors } \\ \text { TCADs } & \text { Tricyclic antidepressants } \\ & \end{array}$




\section{Introduction}

Drug analysis in biological fluids is a very important process for the determination of the physiological performance of a drug for toxicological and clinical purposes [1]. Moreover, the most laborious part of the analytical procedure, which usually takes approx. $80 \%$ of the total analysis time, is the sample preparation of materials of this kind [1-4]. Such biological matrices as blood, serum, or urine are quite complex due to the presence of proteins and other substances with similar chemistry to the analytes $[2,3]$. Thus, it is crucial to select correctly a pretreatment step and an extraction method. Nowadays, in clinical and toxicological laboratories, various sample preparation techniques are applied. The most popular are LLE and solid-phase extraction (SPE). The mechanism of these techniques has been thoroughly investigated.

On the other hand, recently, more efficient and less time- and solvent-consuming techniques compared with the ones mentioned above have been developed-in particular, ones in which the isolation process has been miniaturized [1, 5, 6]. Major examples are $\operatorname{SPME}[1,7]$, LPME [8, 9], and microextraction by packed sorbent (MEPS) [1,2]. The latter is a modern isolation technique based on the miniaturization of a traditional full-scale solid-phase extraction technique [1, 4, 5]. In MEPS, a sorbent is placed within a special needle or barrel, acting as a cartridge. This technique requires several steps: conditioning, application of a studied sample, sorbent washing, and desorption of analytes from the cartridges. These steps seem to be similar to the SPE method, but for MEPS, the sample preparation time, the sample volume, and the organic solvent consumption are significantly reduced. Moreover, the MEPS sorbent may be used about 30100 times for biological material preparation [10-12]. By comparison, the typical SPE cartridges are recommended for single use only. Additionally, the MEPS may be connected off-line and on-line with an LC or GC system $[2,3,5]$.

MEPS was invented and developed in the laboratories of AstraZeneca in Sweden [4-6]. The first communication about the application of this technique to chemical and toxicological analysis was published in 2004 [5]. Abdel-Rehim reported the successful application of the MEPS method connected on-line with GC-MS to the determination of local anesthetics in human plasma. Since that date, microextraction by packed sorbent, thanks to the various numbers of packing beds $(\mathrm{C} 2, \mathrm{C} 8, \mathrm{C} 18, \mathrm{C} 8$-SCX, and molecularly imprinted polymers), has been used to isolate a wide range of organic substances, such as local anesthetics and their metabolites [5, 6, 13], statins [11], anticancer agents $[12,14]$, new-generation antidepressants $[15,16]$, methadone [17], and illegal drugs [2, 18], in difficult biological matrices, e.g., plasma [19], urine [10], saliva [16], and even human hair [18]. Recently, AbdelRehim [20] published a tutorial on microextraction by packed solvent, discussing this new applied sample preparation method for drug analysis combined with LC-MS and GC-MS.

The most interesting study for the authors of the present paper-due to the subject of the research-was performed by Chaves et al. [15]. In their work, microextraction in packed sorbent and liquid chromatography with UV detection was applied to the determination of newgeneration antidepressants (sertraline, mirtazapine, fluoxetine, citalopram, paroxetine) in human plasma. The optimized method was adequate for an analysis of the studied drugs at levels ranging from therapeutic to toxic. The accuracy of the MEPS/LC-UV method for new antidepressants determination was within a range from $84 \%$ to $97 \%$. However, to the authors' knowledge, there has only been one paper, by Malik et al., describing the application of microextraction in packed sorbent to the isolation of tricyclic antidepressant drugs-imipramine, amitriltyline, and clomipramine - from spiked human plasma and urine [21]. The validation (including accuracy assessment) was performed using spiked biological fluid samples.

Within the framework of this research, a method of microextraction in packed sorbent followed by highperformance liquid chromatography with diode array detection was developed, optimized, and validated for the analysis of tricyclic antidepressants (TCADs) and their metabolites (amitriptyline, desipramine, doxepin, imipramine, nordoxepin, nortriptyline) in human serum.

\section{Experimental}

Reagents and materials

HPLC gradient grade acetonitrile and methanol were supplied by Merck (Darmstadt, Germany); 85\% phosphoric acid, 30\% $\mathrm{NaOH}$ aqueous solution, sodium chloride, formic acid, acetic acid, ethyl acetate, chloroform, isopropyl alcohol, $25 \%$ aqueous solution of ammonium and dichloromethane, all of analytical grade, were purchased from POCH (Gliwice, Poland). Drug standards of amitriptyline (Ami), desipramine (Des), doxepin (Dox), imipramine (Imi), nordoxepin (Nord), nortriptyline (Nort), and clomipramine (Clo)all solid hydrochloride salts and diethylamine-were purchased from Sigma-Aldrich (St. Louis, MO, USA). Deionized water $(<1.0 \mu \mathrm{S} / \mathrm{cm})$ was used throughout. Human serum was provided courtesy of the local blood bank (Kraków, Poland). The reference lyophilized serum samples (high-range tricyclic antidepressants V-serum toxicology control, toxicology quality control materials: Clinical \& Forensic, LOT no. 2121) containing four triyclic antidepressant drugs-desipramine, nortriptyline, 
imipramine, and amitriptyline-were obtained from UTAK Laboratories, Inc. (Valencia, CA, USA).

\section{Standards}

Drug stock solutions $(10 \mathrm{mg} / \mathrm{mL})$ were prepared in methanol and stored in a refrigerator $\left(+4{ }^{\circ} \mathrm{C}\right)$. Spiking solutions were prepared by appropriately diluting stock solutions with water. Working standard drug mixtures were prepared by adding a suitable amount of spiking solution to water. For determination of extraction efficiency at the optimization step, a comparative water-based standard containing each drug - Ami, Des, Dox, Imi, Nord, Nortwas spiked at concentrations of 1.15 and $0.63 \mu \mathrm{g} / \mathrm{mL}$ to water $(\mathrm{Clo}, 4.0 \mu \mathrm{g} / \mathrm{mL})$.

Apparatus and conditions

Merck-Hitachi LaChrom high-performance liquid chromatography system consisted of an L-7100 pump and L-7455 programmable diode array detector module coupled to a PC with D-7000 HSM software (Darmstadt, Germany). The mobile phase was prepared by mixing acetonitrile and phosphoric buffer $(40: 60, v / v)$. Phosphoric buffer (pH 2.36) was prepared by adding $1.4 \mathrm{~mL}$ of $85 \%$ phosphoric acid and $1 \mathrm{~mL}$ of diethylamine to a volumetric flask $(1 \mathrm{~L})$ and filling up with deionized water to the mark. Before analysis, the mobile phase was filtered with a modified cellulose filter $(0.45 \mu \mathrm{m})$ by Sartorius (Goettingen, Germany) and degassed in an ultrasonic bath for $15 \mathrm{~min}$. In each analysis, $10 \mu \mathrm{L}$ of sample was injected by an autosampler and the separation carried out in isocratic mode using a Spheri-5 C18 column, $100 \times 4.6-\mathrm{mm} \mathrm{I}$. D., particles $5 \mu \mathrm{m}$ by PerkinElmer (Waltham, MA, USA) for $25 \mathrm{~min}$. The flow rate was $1 \mathrm{~mL} / \mathrm{min}$. The column was thermostated at $50{ }^{\circ} \mathrm{C}$. Chromatograms were acquired at $210 \mathrm{~nm}$ and the calibration curves calculated using peak height ratios (drug/internal standard (IS)).

The MEPS system containing a $250-\mu \mathrm{L}$ syringe coupled with barrel insert and needle assemblies (BINs) packed with C18, C8, and C8-SCX sorbents (4 mg) was purchased from SGE (Melbourne, Australia). All steps of the MEPS procedure were carried out manually (off-line). The SPE J.T. Baker system with Bond Elut Certify (130 mg, $3 \mathrm{~mL}$ ) was purchased from Varian (Palo Alto, CA, USA).

\section{Sample preparation}

The water samples which were used during the optimization step were prepared by adding spiking solution to a $100-\mathrm{mL}$ flask and diluting with $0.9 \% \mathrm{NaCl}$ to the mark of the volumetric flask. The concentration of each drug was $0.25 \mu \mathrm{g} / \mathrm{mL}$. A pH modifier was added to the water samples before MEPS extraction. For $\mathrm{C} 8$ and $\mathrm{C} 18$ BINs, $100 \mu \mathrm{L}$ of $1 \mathrm{M} \mathrm{NaOH}$ and for C8-SCX $100 \mu \mathrm{L}$ of water were added to $1 \mathrm{~mL}$ of sample.

Drug-free human serum was stored at $+4{ }^{\circ} \mathrm{C}$. Of the serum samples, $500 \mu \mathrm{L}$ was spiked with spiking solutions of all analyzed TCADs to $0.25 \mu \mathrm{g} / \mathrm{mL}$ and diluted $1: 1$ with water just before analysis. In the validation step, the diluted drug-free serum was spiked with all six analytes within the range $0.13-1.00 \mu \mathrm{g} / \mathrm{mL}$ and with internal standard $(20 \mu \mathrm{L}$ of $100 \mu \mathrm{g} / \mathrm{mL}$ solution) to a concentration of $2 \mu \mathrm{g} / \mathrm{mL}$.

The human serum reference material was prepared according to the recommendations given by the manufacturer by dissolving lyophilized material with $5 \mathrm{~mL}$ of deionized water. Then, $500 \mu \mathrm{L}$ of the reference serum was diluted 1:1 with water and finally spiked with IS (20 $\mu \mathrm{L}$ of $100 \mu \mathrm{g} / \mathrm{mL}$ of IS solution).

Extraction procedure

\section{MEPS condition}

MEPS was performed using a $250-\mu \mathrm{L}$ volume syringe. Before being used for the first time, a BIN was conditioned with $250 \mu \mathrm{L}$ of methanol followed by $250 \mu \mathrm{L} 0.1 \%$ formic acid. After that, $5 \times 50 \mu \mathrm{L}$ of spiked human serum diluted with water $(1: 1, v / v)$ was drawn through a BIN very slowly to provide sufficient interaction between the analytes and the sorbent. Then, to remove interfering agents, the BIN was washed with $4 \times 50 \mu \mathrm{L}$ of $0.1 \%$ formic acid and next dried by blowing $2 \times 50 \mu \mathrm{L}$ of air. In the following step, the analyzed drugs were eluted by $4 \times 100 \mu \mathrm{L}$ of methanol/ water/ammonia solution $(25 \%, 95: 4: 1, v / v / v)$ to Eppendorf vials $(500 \mu \mathrm{L})$. The MEPS cartridge was rinsed with $2 \times$ $250 \mu \mathrm{L}$ of methanol and then $250 \mu \mathrm{L}$ of $0.1 \%$ formic acid to be ready for preparation of the following sample. After use, the cartridge was filled with methanol, sealed, and stored at room temperature.

The eluate was evaporated under nitrogen stream with mild heating $\left(42^{\circ} \mathrm{C}\right)$. Dry residues were dissolved in $50 \mu \mathrm{L}$ of appropriate medium: with IS $(4 \mu \mathrm{g} / \mathrm{mL})$ - during optimization or just $0.05 \%$ phosphoric acid-in the validation study. The obtained solution was finally transferred to HPLC vials (100- $\mu \mathrm{L}$ capacity).

\section{SPE conditions}

The SPE procedure was taken from an application note by Varian developed for the extraction of tricyclic antidepressants from serum. One milliliter of the spiked serum sample was diluted with $4 \mathrm{~mL} 0.1 \mathrm{M}$ phosphate buffer ( $\mathrm{pH}$ 6.0) and mixed. Before extraction, the SPE cartridge was conditioned with $2 \mathrm{~mL}$ of methanol, $2 \mathrm{~mL}$ of water, and $1 \mathrm{~mL}$ of $0.1 \mathrm{M}$ phosphate buffer $(\mathrm{pH} 6.0)$ 
using low vacuum $(<3$ in. $\mathrm{Hg})$. Then, the sample was applied at low speed $(1-2 \mathrm{~mL} / \mathrm{min})$. After that, the cartridge was washed with $3 \mathrm{~mL}$ of water and $1 \mathrm{~mL}$ of $1 \mathrm{M}$ formic acid followed by $3 \mathrm{~mL}$ of methanol. The sorbent was next dried under vacuum for $5 \mathrm{~min}$. The studied analytes were eluted with $2 \mathrm{~mL}$ of dichloromethane/isopropyl alcohol/ammonia solution (25\%, $78: 20: 2, v / v / v)$ to a glass vial. In the next step, the extraction solvent was evaporated under a nitrogen stream with mild heating $\left(42{ }^{\circ} \mathrm{C}\right)$. Dry residues were treated the same way as in the MEPS procedure.

\section{Results and discussion}

\section{Optimization of MEPS conditions}

Within the framework of this research, a few factors, such as the kind of MEPS sorbent, draw-eject volume, and MEPS procedure, were evaluated to determine the optimal procedure for the isolation of six TCAD drugs from serum samples. At the beginning, all experiments were performed with $0.9 \% \mathrm{NaCl}$ aqueous solution, and then the method was applied to serum samples.

\section{Optimization using water-based samples}

First of all, every step of the MEPS procedure, including the conditioning of sorbent, washing, and the elution of analytes, was developed. As tricyclic antidepressants are usually isolated by solid-phase extraction using $\mathrm{C} 8, \mathrm{C} 18$, and C8-SCX sorbents [22], MEPS cartridges with the same bed types were chosen in our study. Every sorbent was evaluated using four different procedures, listed in Table 1. The choice of solvents and solutions used for cleaning, conditioning, and washing was based on the kind of drug analyzed ( $\mathrm{p} K_{\mathrm{a}}$ over 9.5) and the type of MEPS cartridge. The choice of proposed sets of solvents was carefully based on previous experiments with solid-phase extraction [22] and the authors' routine laboratory work. During the optimization using water-based samples, $500 \mu \mathrm{L}$ of sample solution was drawn and ejected through the cartridge. The aim of washing solvents was to clean the cartridge of potentially interfering substances with minimum loss of the studied compounds. For hydrophobic sorbents such as $\mathrm{C} 8$ and $\mathrm{C} 18$, a water plug was applied, whereas for the C8SCX sorbent, aqueous solutions of formic and acetic acids and mixtures of water with acetonitrile or methanol were tested. After the washing step, sorbents were dried by blowing of $100 \mu \mathrm{L}$ of air. At the elution step, for non-polar beds, elution is faster and more efficient when solvents with medium polarity are applied. This is why a mixture of short-chain alcohols with chloroform or water without

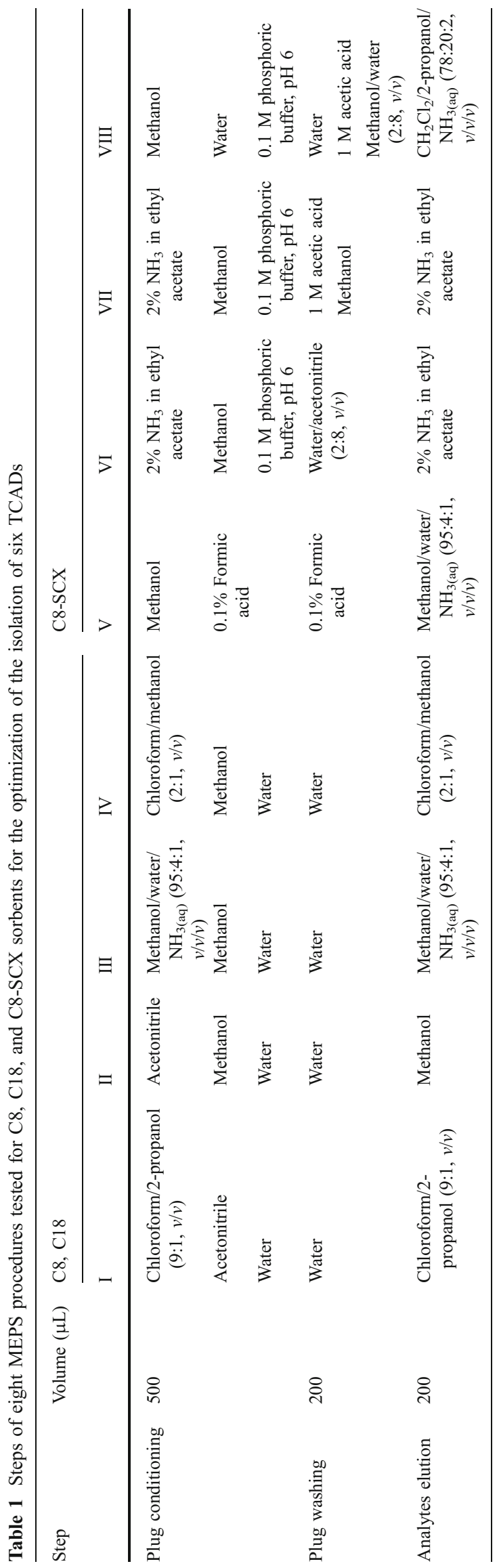


ammonia solution (or with ammonia solution to evaluate differences between non-polar and mixed beds) or even pure methanol was applied. In the case of elution from mixed beds, containing non-polar sorbents and cation exchangers, these also have to be provided with medium polar solutions, but significantly alkalized with ammonia. After use, the BINs (C8, C18, and mixed bed) were always cleaned with $500 \mu \mathrm{L}$ of methanol.

The carryover between samples was controlled by the analysis of a blank sample. This was always done after a sample at the highest concentration of TCADs $(1 \mu \mathrm{g} /$ $\mathrm{mL}$ ) in serum. As the blank sample gave no peaks within the time corresponding to the analyzed drugs, the carryover was estimated to be significantly less than the LOD of the method.

At this step, in order to find the best way of sample preparation and MEPS procedure for each evaluated sorbent, water-based samples spiked with all the studied TCADs were analyzed in 12 separate experiments, repeated five times. Evaluation of the obtained results was performed using a function $F$, which was based on the mean peak height corresponding to the six analytes obtained within a set of five extractions. As an analytical procedure should provide precise results, the repeatability of extraction was also taken into account:

$F=\frac{F^{\prime}}{\max \left(F^{\prime}\right)}$

$F^{\prime}=H \cdot k^{2}$

where $\max \left(F^{\prime}\right)$ is the maximum value of function $F^{\prime}$ in a set of tested procedures, $H$ is the mean peak height corresponding to each of six analytes obtained within the set of five extractions, and $k$ is the number of analytes giving the repeatability of peak height corresponding to each of the six analytes obtained within the set of five extractions with RSD $\leq 10 \%$. According to the proposed approach, function $F^{\prime}$ increases together with $H$ when the extraction efficiency is also high for every drug. As the $H$ value is an average, it represents the extraction efficiency for all the analyzed TCADs. Function $F^{\prime}$ also increases with the $k$ value; however, $k$ ranges from 0 (repeatability of peak height worse than $10 \%$ RSD for all analytes) to 6 (RSD $\leq 10 \%$ of peak height for all six drugs). To provide better comparable results, the $F^{\prime}$ function was normalized by its maximum value.

For the $\mathrm{C} 8$ sorbent, the best procedure (IV) gave a repeatability of relative peak height $(H, n=5)$ below $6 \%$ for all TCADs. For the other procedures (I-III), the repeatability of the analytical signal was very poor (RSD $\%$ more than $25 \%$ ). The mixed sorbent (C8-SCX) required different procedures (V-VIII). Among them, procedure V provided satisfactory results, with $\mathrm{RSD} \%$ within a range from $5 \%$ to $10 \%$. Unexpectedly, the application of the $\mathrm{C} 18$ sorbent also resulted in low repeatability of the peak height. In the best conditions (procedure IV), the RSD\% varied between $5 \%$ and $17 \%$.

In the optimization process, the absolute peak height was also taken into account as its high values provide better sensitivity. Among all approaches, procedures IV (both for $\mathrm{C} 8$ and $\mathrm{C} 18)$ and $\mathrm{V}(\mathrm{C} 8-\mathrm{SCX})$ resulted in the highest peaks (Fig. 1).

The obtained results of function $F$ are presented in Table 2. The calculated $F$ values confirmed that procedures IV (C8) and V (C8-SCX) should be further considered, while despite providing good sensitivity, the application of procedure IV with the $\mathrm{C} 18$ sorbent turned out to be unsuitable for further investigation.

\section{Optimization of sample and elution solvent volume}

In the next step, the draw-eject sample volume at two levels of 250 and $500 \mu \mathrm{L}$ was investigated. A higher intensity of response (peak height) for all TCADs on the chromatograms was obtained for a volume of $500 \mu \mathrm{L}$. Although a sample volume of $500 \mu \mathrm{L}$ provided approx. two times better sensitivity, the lifetime of each BIN was subsequently reduced (from 40 analyses to approx. 20-15 analyses). Thus, in this case, the application of MEPS did not achieve its main goal: being an economic alternative to SPE. That is why the sample volume of $250 \mu \mathrm{L}$ was selected for further analysis.

The elution solvent volume at three levels-100, 200, and $400 \mu \mathrm{L}$-was also evaluated. On the basis of the obtained results, $400 \mu \mathrm{L}$ of the elution volume turned out to

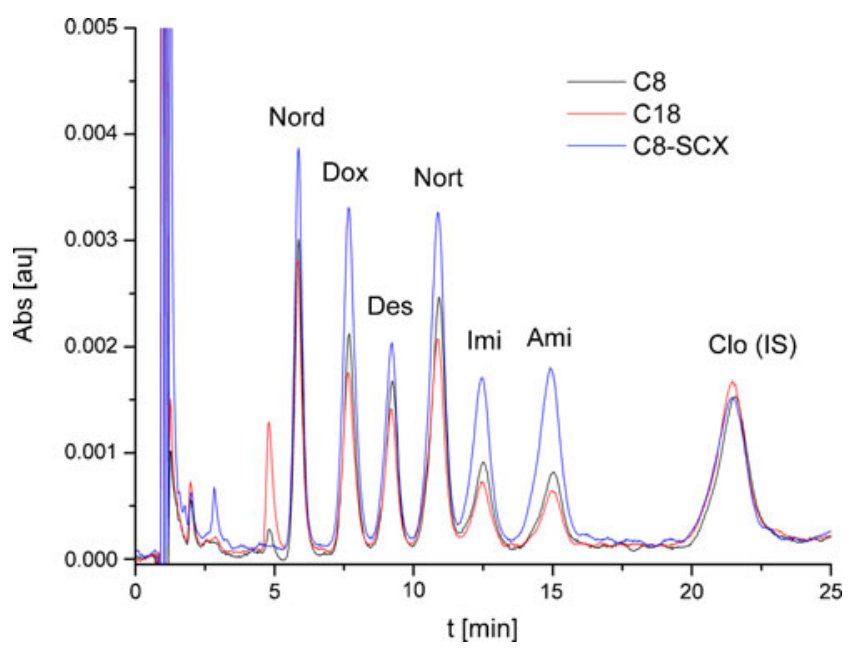

Fig. 1 Comparison between the results obtained at optimal extraction conditions: $\mathrm{C} 8$ - procedure IV, $\mathrm{C} 18$ - procedure IV, C8-SCXprocedure $\mathrm{V}$ 
Table 2 Values of function $F$

\begin{tabular}{|c|c|c|c|}
\hline \multirow[t]{2}{*}{ Procedure } & \multicolumn{3}{|c|}{ Sorbent type } \\
\hline & $\mathrm{C} 8$ & $\mathrm{C} 18$ & C8-SCX \\
\hline I & 0.02 & 0.05 & $-^{\mathrm{b}}$ \\
\hline II & $0.00^{\mathrm{a}}$ & 0.02 & $-{ }^{\mathrm{b}}$ \\
\hline III & 0.01 & $0.00^{\mathrm{c}}$ & $-{ }^{\mathrm{b}}$ \\
\hline IV & 1.00 & 0.10 & $-{ }^{\mathrm{b}}$ \\
\hline V & $-^{\mathrm{b}}$ & $-^{\mathrm{b}}$ & 0.85 \\
\hline VI & $-{ }^{\mathrm{b}}$ & $-{ }^{\mathrm{b}}$ & 0.05 \\
\hline VII & $-{ }^{b}$ & $-{ }^{\mathrm{b}}$ & $0.00^{\mathrm{a}}$ \\
\hline VIII & $-{ }^{\mathrm{b}}$ & $-{ }^{\mathrm{b}}$ & $0.00^{\mathrm{c}}$ \\
\hline
\end{tabular}

${ }^{a}$ No peaks corresponding to analytes detected

${ }^{\mathrm{b}}$ Procedures not tested as they are not suitable for a particular type of sorbent

${ }^{\mathrm{c}}$ Repeatability (RSD\%) for all peaks corresponding to the analytes were poor $(\mathrm{RSD} \%>10 \%)$

elute the studied compounds from both $\mathrm{C} 8$ and C8-SCX cartridges with the highest efficiency. The extraction efficiency was calculated as the ratio of relative peak height $\left(H / H_{\mathrm{IS}}\right)$ obtained for an extracted sample to the relative peak height $\left(H / H_{\mathrm{IS}}\right)$ obtained from the analysis of a standard water-based drug mixture spiked at a concentration of $1.15 \mu \mathrm{g} / \mathrm{mL}$ (the concentration corresponding to $100 \%$ extraction efficiency, including enrichment factor). The concentration of the internal standard was equal in extracted samples and standard water-based mixtures as IS was added after the extraction process. The extraction yields of the analyzed drugs for C8 and C8-SCX were approximately total $(100 \%)$. The repeatability of the calculated extraction efficiency was within the range 2$9 \%$ and $3-10 \%$ for $\mathrm{C} 8$ and C8-SCX, respectively. The effect of extraction efficiency for all studied elution volumes is presented in Fig. 2.

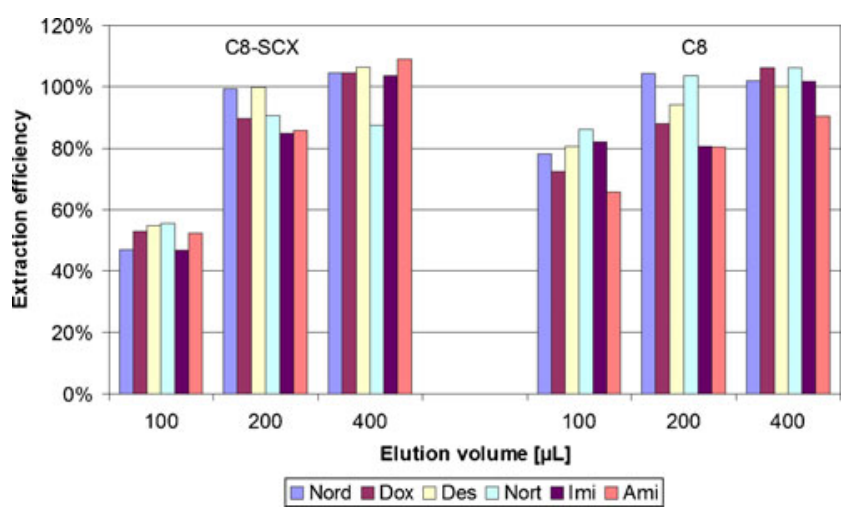

Fig. 2 Comparison between the extraction efficiency for the studied elution volumes $(100,200,400 \mu \mathrm{L})$ for two sorbents, C8-SCX and C8
As the sample volume was relatively high, the volume of conditioning and cleaning solvents also had to be appropriately adjusted. The conditioning volume was found to be equivalent to the sample volume to limit the deterioration of the BIN life. The volume of cleaning solvent reached as much as $200 \mu \mathrm{L}$, but this amount significantly reduced the amount of unknown peaks resulting from the biological matrix.

The results of the extraction of TCADs from spiked water samples using both types of sorbent turned out to be satisfactory, including no detectable carryover, estimated for water samples. Thus, both C8 and C8-SCX with their optimal procedures (IV and $\mathrm{V}$, respectively) were applied to isolate the studied drugs from human serum samples (Fig. 3). The extraction efficiency (calculated in the same manner as for water samples, but including enrichment factor) for C8-SCX varied from $97 \%$ for Des to $111.6 \%$ obtained for Ami. The application of C8 sorbent resulted in efficiency values ranging from $62.9 \%$ (Ami) to $114.7 \%$ (Dox). Repeatability (RSD\%) for all analytes was $<11 \%$ for both sorbents. A low extraction efficiency of nortriptyline and amitriptyline was obtained using the $\mathrm{C} 8$ sorbent, in contrast to the high values-similar for all analytescalculated for C8-SCX, indicating the mixed sorbent to be the optimal one.

\section{Comparison of MEPS and SPE}

The optimized microextraction by packed sorbent procedure of the isolation of six TCADs from serum was then compared with the solid-phase extraction method. As a reference SPE procedure, the extraction of tricyclic antidepressants from serum using Bond Elut Certify (mixed bed, C8-SCX) described in the application note by Varian was chosen. The obtained extraction efficiency ranged from $37.4 \%$ for Nort $(\mathrm{RSD}=4.0 \%$ ) to $101.3 \%$ for Dox $(\mathrm{RSD}=7.4 \%)$. In reference papers, the application

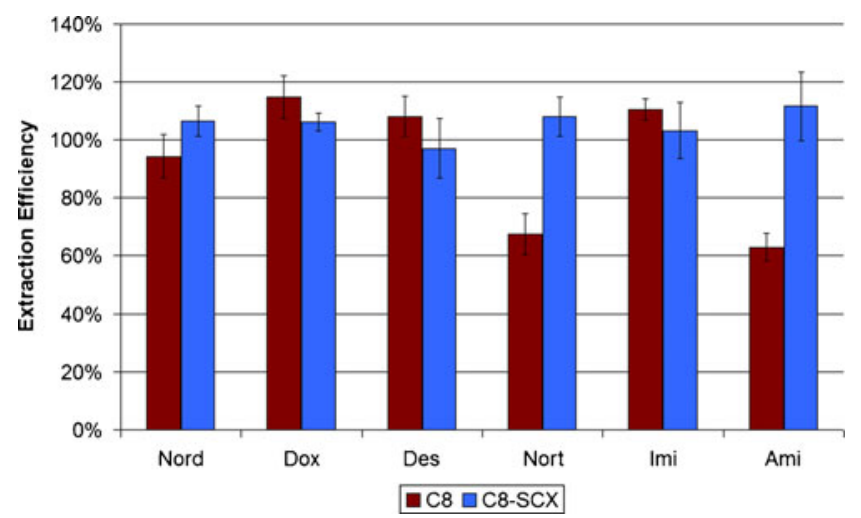

Fig. 3 Extraction efficiency of the studied TCADs from serum samples using sorbents C8 and C8-SCX 
of optimized SPE procedures using the same SPE columns resulted in the following extraction efficiencies: $62 \%$ Nort, 63\% Clo, 66\% Des, 69\% Ami, and 82\% Imi $[23,24]$. It should be emphasized that the application of SPE columns resulted in four times larger sample amounts, and a single sample produced $14 \mathrm{~mL}$ of disposals (procedure [23, 24] produced even more sample and solvents). In the case of the MEPS procedure, waste production is only about $1.5 \mathrm{~mL}$ per sample.

Method validation

Validation of the off-line MEPS/HPLC-DAD method for the determination of six tricyclic antidepressants and their metabolites in human serum was performed. Another tricyclic antidepressant, clomipramine, was chosen as the internal standard. The results are presented in Table 3. The analysis of blank samples (analyte-free serum and water samples) revealed that there was no agent interfering with the analyzed tricyclic antidepressants.

The LOD and LOQ were calculated as three and ten times the standard deviation of the analytical signal at the $0.2-\mu \mathrm{g} / \mathrm{mL}$ concentration level and slope coefficient ratio $\left(\mathrm{SD}_{0.2} / \mathrm{slope}\right)$, respectively. The calculated LOD values ranged from $0.02 \mu \mathrm{g} / \mathrm{mL}$ (Nord, Nort) to $0.05 \mu \mathrm{g} /$ $\mathrm{mL}$ (Imi, Ami). The linearity range was expressed as the range from the LOQ to the maximum measured concentration $(1 \mu \mathrm{g} / \mathrm{mL})$ with respect to $R^{2}>0.9995$. The obtained values allowed the determination of TCADs present in serum both at therapeutic levels and at concentrations found in lethal cases.

The precision of the developed method, expressed as the repeatability of the determined concentration, was estimated by an analysis of five different serum samples spiked with analytes at concentration levels of $0.2,0.5$, and $0.8 \mu \mathrm{g} / \mathrm{mL}$. The measurements were repeated three times on the next days. In this way, intraday and interday precision was determined (see Table 3 ).

The accuracy of the assay $(A)$ was calculated as the ratio of the found concentration $\left(C_{\mathrm{f}}\right)$ to the expected concentration $\left(C_{\mathrm{e}}\right)$ after spiking a sample. It was examined at the three concentration levels; every level was examined in four separate experiments.

$A=\frac{C_{\mathrm{f}}}{C_{e}} \times 100 \%$

The obtained results from the analysis of four samples are presented in Table 4 . The accuracy of the assay ranged from $96.8 \pm 8.7 \%$ (Ami) to $106.0 \pm 5.3 \%$ (Des) at a low concentration level $(0.2 \mu \mathrm{g} / \mathrm{mL}), 94.5 \pm 5.3 \%$ (Ami) to $103.0 \pm 8.8 \%$ (Des) at a medium concentration level $(0.5 \mu \mathrm{g} / \mathrm{mL}$ ), and from $100.2 \pm 6.8 \%$ (Dox) to $108.8 \pm 2.0 \%$ (Des) at a high concentration level $(0.8 \mu \mathrm{g} / \mathrm{mL})$. The accuracy of the determination of all studied TCADs obtained using the MEPS/HPLC-DAD method was compared with those achieved by the SPE/HPLC-DAD method (see Table 4). In this case, the calculated accuracy values ranged from $107.5 \pm 3.3 \%$ (Ami) to $113.7 \pm 4.9 \%$ (Imi) at a low concentration level, $101.5 \pm 6.5 \%$ (Nord) to $106.6 \pm$ $2.9 \%$ (Ami) at a medium concentration level, and from $99.2 \pm 3.9 \%$ (Nord) to $106.9 \pm 3.7 \%$ (Dox) at a high concentration level. According to the obtained results, it may be stated that both methods are quite similar, providing nearly $100 \%$ accuracy with a suitable precision, especially in the case of the analysis of biological material.

Table 3 Validation parameters of the MEPS/HPLC method of determination of six TCADs in human serum

\begin{tabular}{|c|c|c|c|c|c|c|c|}
\hline \multicolumn{2}{|l|}{ Parameter } & Nord & Dox & Des & Nort & Imi & Ami \\
\hline \multicolumn{2}{|l|}{ Linearity $(\mu \mathrm{g} / \mathrm{mL})$} & \multicolumn{6}{|c|}{$\mathrm{LOQ}=1.0(n=5)$} \\
\hline \multicolumn{2}{|l|}{ Slope } & 5.92 & 3.01 & 1.68 & 2.29 & 1.02 & 1.56 \\
\hline \multicolumn{2}{|l|}{ Intercept } & -0.013 & -0.003 & -0.006 & -0.002 & 0.017 & 0.005 \\
\hline \multicolumn{2}{|l|}{ Correlation coefficient, $R^{2}$} & 0.9998 & 0.9998 & 0.9997 & 0.9998 & 0.9995 & 0.9996 \\
\hline \multicolumn{2}{|l|}{$\mathrm{LOD}(\mu \mathrm{g} / \mathrm{mL})$} & 0.02 & 0.03 & 0.03 & 0.02 & 0.05 & 0.05 \\
\hline \multicolumn{2}{|l|}{ LOQ $(\mu \mathrm{g} / \mathrm{mL})$} & 0.08 & 0.09 & 0.11 & 0.08 & 0.17 & 0.17 \\
\hline \multirow[t]{2}{*}{ Precision $0.2 \mu \mathrm{g} / \mathrm{mL}, \mathrm{RSD}(\%)$} & Intraday $^{\mathrm{a}}$ & 4.2 & 4.4 & 5.2 & 4.1 & 8.1 & 8.8 \\
\hline & Interday $^{\mathrm{b}}$ & 4.4 & 10.5 & 5.8 & 5.7 & 7.9 & 11.6 \\
\hline \multirow[t]{2}{*}{ Precision $0.5 \mu \mathrm{g} / \mathrm{mL}$. RSD (\%) } & Intraday $^{\mathrm{a}}$ & 5.0 & 3.7 & 3.7 & 4.0 & 7.6 & 5.4 \\
\hline & Interday ${ }^{\mathrm{b}}$ & 6.2 & 6.9 & 6.0 & 6.4 & 6.5 & 7.1 \\
\hline \multirow[t]{2}{*}{ Precision $0.8 \mu \mathrm{g} / \mathrm{mL}$. RSD (\%) } & Intraday $^{\mathrm{a}}$ & 2.7 & 4.8 & 3.2 & 2.9 & 5.7 & 4.8 \\
\hline & Interday $^{\mathrm{b}}$ & 10.3 & 5.9 & 10.7 & 10.8 & 6.5 & 8.6 \\
\hline
\end{tabular}

${ }^{\mathrm{a}} n=5$

${ }^{\mathrm{b}} n=20$ (4 days, within 2 weeks, five replicates each day) 
Table 4 Accuracy of the assay of TCADs in human serum obtained after MEPS and SPE extraction $(n=4)$

\begin{tabular}{|c|c|c|c|c|c|c|c|c|c|c|}
\hline \multirow[t]{2}{*}{ Method } & \multirow[t]{2}{*}{ Drug } & \multicolumn{3}{|c|}{ Low concentration level $(\mu \mathrm{g} / \mathrm{mL})$} & \multicolumn{3}{|c|}{ Medium concentration level $(\mu \mathrm{g} / \mathrm{mL})$} & \multicolumn{3}{|c|}{ High concentration level $(\mu \mathrm{g} / \mathrm{mL})$} \\
\hline & & Expected & Found & Accuracy $(\%)$ & Expected & Found & Accuracy $(\%)$ & Expected & Found & Accuracy $(\%)$ \\
\hline \multirow[t]{6}{*}{ MEPS } & Nord & 0.200 & 0.199 & $99.4 \pm 4.1$ & 0.500 & 0.503 & $100.6 \pm 7.5$ & 0.800 & 0.850 & $106.2 \pm 5.3$ \\
\hline & Dox & & 0.194 & $97.2 \pm 4.2$ & & 0.483 & $96.6 \pm 2.6$ & & 0.801 & $100.2 \pm 6.8$ \\
\hline & Des & & 0.212 & $106.0 \pm 5.3$ & & 0.515 & $103.0 \pm 8.8$ & & 0.871 & $108.8 \pm 1.9$ \\
\hline & Nort & & 0.202 & $100.9 \pm 3.9$ & & 0.512 & $102.3 \pm 9.3$ & & 0.846 & $108.0 \pm 2.0$ \\
\hline & Imi & & 0.197 & $98.2 \pm 8.5$ & & 0.496 & $98.9 \pm 3.4$ & & 0.813 & $101.6 \pm 6.0$ \\
\hline & Ami & & 0.194 & $96.8 \pm 8.7$ & & 0.473 & $94.5 \pm 5.3$ & & 0.805 & $100.6 \pm 3.5$ \\
\hline \multirow[t]{6}{*}{ SPE } & Nord & 0.200 & 0.220 & $110.1 \pm 8.7$ & 0.500 & 0.515 & $101.5 \pm 6.5$ & 0.800 & 0.805 & $99.2 \pm 3.9$ \\
\hline & Dox & & 0.225 & $112.4 \pm 5.2$ & & 0.523 & $103.9 \pm 5.1$ & & 0.863 & $106.9 \pm 3.7$ \\
\hline & Des & & 0.233 & $111.6 \pm 9.1$ & & 0.519 & $102.8 \pm 6.0$ & & 0.848 & $105.1 \pm 3.1$ \\
\hline & Nort & & 0.220 & $110.0 \pm 8.6$ & & 0.517 & $103.8 \pm 3.8$ & & 0.850 & $105.2 \pm 2.2$ \\
\hline & Imi & & 0.227 & $113.7 \pm 4.9$ & & 0.533 & $106.3 \pm 5.5$ & & 0.824 & $101.8 \pm 3.8$ \\
\hline & Ami & & 0.215 & $107.5 \pm 3.3$ & & 0.535 & $106.6 \pm 2.9$ & & 0.844 & $104.7 \pm 2.1$ \\
\hline
\end{tabular}

In order to determine the accuracy of the MEPS/ HPLC-DAD method, the certified reference material of human serum was analyzed. The experiment was performed four times and the obtained results compared with those achieved by the SPE/HPLC-DAD technique (Table 5). The determined concentrations fitted in the expected range reported by the manufacturer for three of the studied drugs, with the exception of the concentration of nortriptyline found by MEPS/HPLC-DAD. In this case, the obtained concentration values varied around a level higher than the certified concentration range. The analysis of reference material shows that the optimized MEPS extraction method coupled with determination by HPLC$\mathrm{DAD}$ is reliable.

\section{Conclusions}

In this research, a novel MEPS/HPLC-DAD method for the isolation of tricyclic antidepressants from human serum was developed, optimized, and validated. The developed method enables the determination of amitryptyline, nortryptyline, doxepin, nordoxepin, imipramine, and desipramine within a wide concentration range, with good accuracy and suitable precision. Compared with the conventional solid-phase extraction technique, microextraction by packed sorbent is simpler to perform, limiting the volumes of organic solvents and minimizing costs of analysis. Further reduction of sample volume is also possible, but in this case, systems that are more sensitive than DAD detection have to be applied. Moreover, it does not require almost any specialized equipment (e.g., vacuum pump) and may be coupled on-line with GC or HPLC. However, contrary to the manufacturer's leaflet, in our study, the cartridges could be applied more than 40 times for water samples and only about 10 times for serum samples.

The application of the MEPS procedure and equipment at the preparation stage provided satisfying extraction efficiency. Moreover, the good sensitivity and precision and the high accuracy of the assay of tricyclic antidepressant drugs make the MEPS/HPLCDAD method a useful tool in clinical laboratories for therapeutic monitoring of TCADs as well as in forensic laboratories for their determination at therapeutic and higher levels in human fluids.

Table 5 Analysis of serum reference material by MEPS/HPLC and SPE/HPLC $(n=4)$

\begin{tabular}{|c|c|c|c|c|}
\hline Parameter & Des & Nort & Imi & Ami \\
\hline $\begin{array}{l}\text { Concentration verified by the } \\
\text { manufacturer }(\mu \mathrm{g} / \mathrm{mL})\end{array}$ & $0.40(0.34-0.46)^{\mathrm{a}}$ & $0.37(0.31-0.42)^{\mathrm{a}}$ & $0.38(0.32-0.43)^{\mathrm{a}}$ & $0.37(0.32-0.43)^{\mathrm{a}}$ \\
\hline $\begin{array}{l}\text { Found concentration by } \\
\text { MEPS/HPLC }(\mu \mathrm{g} / \mathrm{mL})\end{array}$ & $0.46 \pm 0.09$ & $0.43 \pm 0.01$ & $0.40 \pm 0.01$ & $0.40 \pm 0.01$ \\
\hline $\begin{array}{l}\text { Found concentration by } \\
\text { SPE/HPLC }(\mu \mathrm{g} / \mathrm{mL})\end{array}$ & $0.42 \pm 0.16$ & $0.36 \pm 0.01$ & $0.40 \pm 0.14$ & $0.43 \pm 0.04$ \\
\hline
\end{tabular}

${ }^{\mathrm{a}}$ Expected range given by the manufacturer 
Acknowledgments The authors gratefully acknowledge the financial support of the European Regional Development Fund within the framework of the Innovative Economy Operational Programme (Project MNS-DIAG, POIG 01.03.01-00-014/08-00).

Open Access This article is distributed under the terms of the Creative Commons Attribution Noncommercial License which permits any noncommercial use, distribution, and reproduction in any medium, provided the original author(s) and source are credited.

\section{References}

1. Mullett WM (2007) J Biochem Biophys Methods 70:263-273

2. Jagerdeo E, Abdel-Rehim M (2009) J Am Soc Mass Spectrom 20:891-899

3. Altun Z, Abdel-Rehim M (2008) Anal Chem Acta 630:116-123

4. Novakova L, Vlckova H (2009) Anal Chem Acta 656:8-35

5. Abdel-Rehim M (2004) J Chromatogr B 801:317-321

6. Abdel-Rehim M, Altun Z, Blomberg L (2004) J Mass Spectrom 39:1488-1493

7. Schubert JK, Miekisch W, Fuchs $\mathrm{P}$, Scherzer N, Lord H, Pawliszyn J, Mundkowski RG (2007) Clin Chem Acta 386:57-62

8. Pedersen-Bjergaard S, Rasmussen KE, Brekke A, Si Ho T, Halvorsen TG (2005) J Sep Sci 28:1195-1203

9. de Santana FJM, Bonato PS (2008) Anal Chem Acta 606:80-91

10. El-Beqqali A, Kussak A, Abdel-Rehim M (2007) M J Sep Sci $30: 421-424$
11. Vlckova H, Solichova D, Blaha M, Solich P, Novakova L (2011) J Pharm Biomed Anal 55(2):301-308

12. Said R, Hassan Z, Hassan M, Abdel-Rehim M (2008) J Liq Chromatogr RT 31:683-694

13. Altun Z, Abdel-Rehim M, Blomberg LG (2004) J Chromatogr B 813:129-135

14. Vita M, Skansen P, Hassan M, Abdel-Rehim M (2005) J Chromatogr B 817:303-307

15. Chaves AR, Leandro FZ, Carris JA, Queiroz MEC (2010) J Chromatogr B 878:2123-2129

16. Saracino MA, de Palma A, Boncompagni G, Raggi MA (2010) Talanta 81:1547-1553

17. El-Beqqali A, Abdel-Rehim M (2007) J Sep Sci 30:2501-2505

18. Miyaguchi H, Iwata YT, Kanamori T, Tsujikawa K, Kuwayama K, Inoue H (2009) J Chromatogr A 1216:4063-4070

19. Abdel-Rehim M, Skansen P, Vita M, Hassan Z, Blomberg L, Hassan M (2005) Anal Chem Acta 539:35-39

20. Abdel-Rehim M (2011) Anal Chem Acta 701:119-128

21. Rani S, Kumar A, Malik AK, Singh B (2011) Quantification of tricyclic and nontricyclic antidepressants in spiked plasma and urine samples using microextraction in packed syringe and analysis by LC and GC-MS. Chromatogr 74:235-242. doi:10.1007/s10337-011-2052-0

22. Madej K, Kochana J, Woźniakiewicz M (2007) J Liq Chromatogr Related Technol 30:185-198

23. Martínez MA, Sánchez de la Torre C, Almarza E (2002) J Anal Toxicol 26:296-302

24. Martínez MA, Sánchez de la Torre C, Almarza E (2003) J Anal Toxicol 27:353-358 